\title{
The Phorbol Ester TPA Regulates Collagen Gene Expression at the Transcriptional Level
}

\author{
I. Stuiver*1, M.J.C. Hendrix ${ }^{\#}$, Y. Shimizu ${ }^{\dagger}$, and N. Shimizu ${ }^{* *}$ \\ *,†,**Department of Molecular and Cellular Biology, The University of Arizona, Tucson, AZ 85721 and \\ \#Department of Anatomy, The University of Arizona Medical School, Tucson, AZ 85721
}

Key words: collagen gene/transcription/TPA/protein kinase C/protooncogene

\begin{abstract}
Previously, we reported that growth activation of quiescent 3T3-L1 cells by TPA led to a rapid increase of pro- $\alpha 2$ (I) collagen mRNA and protein, while induction of pro- $\alpha 2$ (I) was not observed in VT-1 cells, a line non-mitogenic in the presence of TPA (26). Here, we further examine the expression of pro- $\alpha 2$ (I) collagen during mitogenic stimulation at the molecular level. In addition to pro- $\alpha 2$ (I) mRNA, TPA treatment increased mRNA production of other collagen family members, pro- $\alpha 1$ (I) and pro- $\alpha 1$ (III) although in reduced amounts relative to pro- $\alpha 2$ (I). In contrast to pro- $\alpha 2$ (I), the mRNA expression profiles of several protooncogenes were regulated in both VT-1 and 3T3-L1 cells. Consistent with increased mRNA levels, TPA treated 3T3-L1 cells produced a matrix abundant in collagen type I protein. In vitro nuclear "run-on" transcription assays demonstrated a 4-fold increase in pro- $\alpha 2$ (I) mRNA that was maximal within $10 \mathrm{~min}$ of TPA treatment. Using a chloramphenicol-acetyl transferase (CAT) assay, we identified a TPA sensitive domain within the promoter of the COL1A2 gene. These results establish COL1A2 as an early growth responsive gene, and that its regulation is PKC dependent. Additionally, the increased expression of protooncogenes and transin during TPA stimulation of non-mitogenic VT-1 cells indicated that the regulation of these genes is independent of PKC, indicating the existence of multiple regulatory mechanisms amongst early response genes.
\end{abstract}

The phorbol ester, TPA, a known activator of protein kinase $\mathrm{C}(\mathrm{PKC})$, has been recognized as a potent mitogen (1-10). Several proteins phosphorylated in response to TPA assist in the progression through the cell cycle $(8,11-16)$. Coincident with increased protein phosphorylation, there is an up-regulation of gene expression. In fact, we and others have shown that TPA can induce the expression of genes thought to play an active role in the cell cycle $(8,16-24)$.

To identify the genes involved in TPA induced DNA synthesis and mitosis, we developed a non-responsive line, VT-1, derived from TPA responsive 3T3-L1 fibro-

*1 Ingrid Stuiver is currently at: The Scripps Research Institute SBR-8, 10666 N. Torrey Pines Rd. La Jolla, CA 92037. Tel: 619-554-2974, Fax: 619-554-6779

\# M.J.C. Hendrix is currently at: The Pediatric Research Institute, Cardinal Glennon Children's Hospital, St. Louis University School of Medicine, 3662 Park Ave.

Tel: 314-577-5623, FAX: 314-268-2748

+ Y. Shimizu is currently at: Department of Medical Genetics, School of Health Sciences, Kyorin University, Hachioji, Tokyo 192, Japan.

Tel: 81-426-91-0011, FAX: 81-426-92-0319

** N. Shimizu is currently at: Department of Molecular Biology, Keio University School of Medicine, Tokyo 160, Japan.

Tel: 81-3-3353-1211, FAX: 81-3-3351-2370

To whom correspondence should be addressed. blasts (3). In VT-1 cells, protein kinase C (PKC) was not translocated to the membrane nor was it capable of phosphorylating its substrate, the $80 \mathrm{kD}$ protein, in the presence of TPA (13). Using the TPA-Inducible Early-5 (TIE-5, shown to be equivalent to the COL1A2 gene) probe obtained by differential hybridization of cDNA from these two cell lines (25), we have shown that TPA causes an increase in steady-state pro- $\alpha 2$ (I) collagen mRNA levels (26). This increase is independent of protein synthesis yet contingent upon the growth status of the cell (26).

To elucidate the mechanism of TPA induced pro$\alpha 2$ (I) collagen gene expression, we have examined the effect of TPA on transcription and translation of this gene. Nuclear run-on experiments revealed that pro- $\alpha 2$ (I) mRNA expression was upregulated in 3T3-L1 cells by TPA. In addition, whole cell immunofluorescence of quiescent 3T3-L1 cells revealed an increase in type I procollagen synthesis after TPA stimulation. These effects were not observed in the TPA non-responsive VT-1 cells. Preliminary analysis of the COL1A2 promoter has identified a TPA sensitive element. In contrast to COL1A2, the early genes c-fos, c-myc, c-jun, transin and the structural genes COL1A1 and COL3A1, were expressed and upregulated in both 3T3-L1 and VT-1 cell lines. These findings suggest multiple regulatory 
mechanisms amongst collagen and early response genes by PKC.

\section{MATERIALS AND METHODS}

Materials. DMEM, FBS, L-glutamine and penicillin/ streptomycin were purchased from GIBCO (Grand Island, NY). 12-O-tetradecanoylphorbol-13-acetate (TPA, phorbol12-myristate-13-acetate) $(100 \mu \mathrm{g} / \mathrm{ml})$, dexamethasone $(1 \mathrm{mg}$ $/ \mathrm{ml})$ and IBMX (2 mg/ml) were purchased from Sigma Chemical Co. (St. Louis, MO) and solubilized in DMSO. Rabbit anti-mouse collagen I polyclonal antisera was purchased from Chemicon (California). Ultra pure cesium chloride was purchased from Fischer (Fairlawn, N.J.). Alpha-[ $\left.{ }^{32} \mathrm{P}\right] \mathrm{CCTP}$ and $\left[{ }^{32} \mathrm{P}\right]$ UTP were purchased from ICN (Costa Mesa, CA). Whatman DE81 ion exchange filter paper $(2.3 \mathrm{~cm}$ discs) was from Whatman International LTD (Maidstone, England). Nytran filters were from Schleicher and Schuell (Keene, NH).

DNA probes. The TPA Inducible Early-5 (TIE-5) cDNA was cloned into the EcoR1 site of pUC-19, provided by M. Amagai (25). This sequence was found to be homologous to the COL1A2 gene. pMCS1.7 containing the second exon of mouse COL1A3 and the reporter clones pR23, pR40 and pAZ1002, were provided by $B$. de Crombrugghe $(27,28)$. pBL3CAT was provided by B. Luckow (29). The pBL3CAT10 vector, generated in this lab, contains the COL1A2 promoter region from $-2,000$ to +54 cloned into pBL3CAT. pEVE.HO which contains the $3^{\prime}$ end of COL1A1 was provided by E. Vuario (unpublished). Murine c-myc MC-29 contains exons 2 and 3 in the EcoRI site of pBR322. The MC-29 probe was provided by Dr. Stuart Kim. The HindIII fragment of pc-fos (mouse)-3 (American Type Culture Collection, Rockville, MD) was used for Northern analysis. pfos-1, also known as pv-fos, containing $1.3 \mathrm{~kb}$ of the v-fos gene, was used for nuclear run on analysis (30). pHJ contains the long open reading frame of human c-jun and was provided by D. Bohmann (31). The transin probe was provided by $T$. Bowden (32). All probes used for Northern analysis were isolated from their respective vectors by restriction digestion and purified by low-melt agarose gel electrophoresis (BioRad, Richmond, CA).

Cell culture. TPA-nonresponsive VT-1 variant cells were isolated from mouse fibroblast 3T3-L1 cells as described (3). Unless otherwise specified, cells were grown to $80 \%$ confluence in Dulbecco's modified Eagle's medium (DMEM) supplemented with $10 \%$ fetal bovine serum (FBS) and growth-arrested for 5 to 6 days in DMEM containing 5\% FBS. Cells were tested regularly for TPA responsiveness using ${ }^{3} \mathrm{H}$-thymidine incorporation assays as previously described $(3,33)$. Briefly, the cultures were treated with DMSO $(0.1 \%)$, TPA $(100 \mathrm{ng} / \mathrm{ml})$ or FBS $(10 \%)$ and cycloheximide $(10 \mu \mathrm{g} / \mathrm{ml})$ was added immediately prior to TPA addition. After treatment, cultures were placed on ice, washed twice with Dulbecco's phosphate buffered saline without $\mathrm{CaCl}_{2}$ and $\mathrm{MgCl}_{2}$ (PBS), detached from plates with teflon-coated razor blades, washed with PBS and stored at $-70^{\circ} \mathrm{C}$ until used.

Total RNA isolation from tissue culture cells. RNA was isolated from cell lines using guanidine isothiocyanate (GUSCN) and $\mathrm{CsCl}$ centrifugation (34). Frozen cell pellets were resuspended in $4 \mathrm{M}$ GUSCN and homogenized. This mixture was then layered onto a $5.7 \mathrm{M} \mathrm{CsCl}$ cushion and centrifuged in a swinging bucket rotor at $32,000 \mathrm{rpm}, 22^{\circ} \mathrm{C}$ for 18 hrs. The resulting pellet was resuspended in diethylpyrocarbonate treated $\mathrm{dH}_{2} \mathrm{O}\left(\right.$ DEPC $\left._{2} \mathrm{O}\right)$ and used for Northern analysis.

Northern analysis. Total RNA was separated by $1.5 \%$ agarose gel electrophoresis in the presence of $2.2 \mathrm{M}$ formaldehyde and transferred to Nytran filters (Schleicher and Schuell, Keene, NH) using $10 \times$ SSC. Filters were prehybridized $(6 \times$ SSC, $10 \times$ Denhardt's, $1 \%$ SDS, $50 \mu \mathrm{g} / \mathrm{ml}$ sonicated salmon sperm DNA) at $42^{\circ} \mathrm{C}$ for $2 \mathrm{hrs}$. Hybridization was done in the presence of $50 \%$ formamide at $42^{\circ} \mathrm{C}$ for $16 \mathrm{hrs}$. ${ }^{32} \mathrm{P}$-labeled cDNA probes were prepared by a random priming method using the Oligo-labeling kit (Pharmacia, Piscataway, NJ). The filters were washed twice for 15 minutes at room temperature in $6 \times \mathrm{SSC}, 0.1 \% \mathrm{SDS}$, twice for $15 \mathrm{~min}$ at $37^{\circ} \mathrm{C}$ in $1 \times \mathrm{SSC}$, $1 \% \mathrm{SDS}$ and once for 2 hours at $65^{\circ} \mathrm{C}$ in $0.1 \times \mathrm{SSC}, 0.1 \%$ SDS and exposed to Konica type A X-ray film with two intensifying screens at $-70^{\circ} \mathrm{C}$. The signals on the autoradiograms were quantitated using a densitometer (E-C Apparatus Corp. St. Petersburg, Florida) or the Betascope 603 blot analyzer (Betagen, Waltham, MA).

Nuclear transcription assay. Approximately $1 \times 10^{7}$ cells were harvested, washed and resuspended in hypotonic buffer (20 mM Tris- $\mathrm{HCl}, \mathrm{pH} 8.0,4 \mathrm{mM} \mathrm{MgCl}, 6 \mathrm{mM} \mathrm{CaCl}_{2}, 0.5$ mM DTT). An equal volume of lysis buffer $(0.6 \mathrm{M}$ sucrose, $0.2 \%$ Triton X-100, $0.5 \mathrm{mM}$ DTT) was added, the contents dounce homogenized, pelleted at $4^{\circ} \mathrm{C}$ and resuspended in a buffer consisting of $0.25 \mathrm{M}$ sucrose, $10 \mathrm{mM}$ Tris- $\mathrm{HCl} \mathrm{pH} \mathrm{8.0,}$ $10 \mathrm{mM} \mathrm{MgCl} 2,1 \mathrm{mM}$ DTT. $1 \times 10^{7}$ nuclei were removed, pelleted, resuspended in reaction buffer $(50 \mathrm{mM}$ Hepes, $\mathrm{pH} 8.0$, $90 \mathrm{mM} \mathrm{NH}{ }_{4} \mathrm{Cl}, 5 \mathrm{mM} \mathrm{MgCl} 2,0.5 \mathrm{mM} \mathrm{MnCl}, 2 \mathrm{mM}$ DTT, $0.1 \mathrm{mM}$ EDTA, $0.4 \mathrm{mM}$ each of ATP, CTP and GTP, $10 \%$ glycerol, $10 \mu \mathrm{g} / \mathrm{ml} \mathrm{BSA}$ ), added to $100 \mu \mathrm{Ci}$ of lyophilized ${ }^{32} \mathrm{P}$ UTP (ICN, Costa Mesa, CA) and incubated at $26^{\circ} \mathrm{C}$ for 30 $\mathrm{min}$. To monitor the reaction, $2 \mu \mathrm{ls}$ of the mixture were spotted onto DE-81 filter disks at the start and finish of each reaction. The filters were washed 5 times in $\mathrm{Na}_{2} \mathrm{HPO}_{4}, 2$ times in $\mathrm{H}_{2} \mathrm{O}$, twice with EtOH, dried and counts determined by scintillation spectrometry. The reaction was terminated by pelleting the nuclei for 20 seconds at $4{ }^{\circ} \mathrm{C}$ and subsequently resuspending the pellet in TE containing $0.3 \%$ SDS and $100 \mu \mathrm{g} / \mathrm{ml}$ yeast tRNA. RNA was harvested by addition of $100 \mathrm{mM}$ NaAcetate $/ 20 \mathrm{mM}$ EDTA to the lysates followed by extraction with water saturated phenol, and centrifugation at $3,000 \mathrm{rpm}$ for $10 \mathrm{~min}$. The organic phase reextracted with $50 \mathrm{mM}$ NaAcetate, $\mathrm{pH} 5.0,10 \mathrm{mM}$ EDTA and $0.2 \%$ SDS and added to the first aqueous phase. RNA was isolated from the aqueous phase by EtOH precipitation and resuspended in DEPC $\mathrm{H}_{2} \mathrm{O}$. The RNA was subsequently reextracted with phenol/ 
chloroform, reprecipitated with NaAcetate and $\mathrm{EtOH}$, and then pelleted. Equal amounts of cpm were added to each hybridization sample. DNA probes were spotted onto Nytran filters (Scheicher and Shuell, Keene, NH) using the BIO-DOT microfiltration apparatus (BioRad, Richmond, CA). The membrane was oven dried and prehybridized in $3 \times \mathrm{SSC}, 5 \times$ Denhardt's, $200 \mu \mathrm{g} / \mathrm{ml}$ yeast tRNA, 50\% formamide, and $1 \%$ SDS overnight at $42^{\circ} \mathrm{C}$. Equal counts of the labeled RNA and $4.8 \%$ dextran sulfate were then added directly to the prehybridization mixture and hybridization was carried out for 3 days at $42^{\circ} \mathrm{C}$. The membranes were then washed 2 times for $15 \mathrm{~min}$ each in $2 \times \mathrm{SSC} / 0.1 \% \mathrm{SDS}$ at $22^{\circ} \mathrm{C}$ and then 2 times for $30 \mathrm{~min}$ in $0.1 \times \mathrm{SSC} / 0.1 \% \mathrm{SDS}$ at $65^{\circ} \mathrm{C}$. The radioactive signals on the membranes were quantified using the Betascope 603 blot analyzer (Betagen, Waltham, MA) and blots then exposed to Konica type A film with Cronex intensifying screens (DuPont, Wilmington, DE).

Whole cell immunofluorescence. Cells were grown on sterile $18 \mathrm{~mm}$ square coverslips \#1.5 (Corning). Cultures at $80 \%$ confluence or in a quiescent state for 5 days in 5\% FBS were treated with TPA $(100 \mathrm{ng} / \mathrm{ml})$ for $2 \mathrm{hrs}$. The cells were fixed with $3.7 \%$ formaldehyde for $15 \mathrm{~min}$ at $22^{\circ} \mathrm{C}$ and washed twice with PBS. Fixed cells were stained using rabbit antimouse collagen I (Chemicon, California) as the primary antibody and rhodamine-conjugated goat anti-rabbit IgG as the secondary antibody. The coverslips were then mounted with gelvitol (Monsanto, St. Louis, MO), and fluorescent images were obtained using a Zeiss standard model 18 microscope (equipped with an automatic rhodamine and fluorescein filter set). Photographs were taken using Ilford black and white, ASA 400 film. The fluorescence intensity of each slide was quantitated by a BioRad confocal laser scanning microscope equipped with an MRC600 image analyzer.

Chloramphenicol acetyl transferase assay. $5 \times 10^{5}$ cells were transfected with 1-10 $\mu \mathrm{g}$ of DNA using the calcium phosphate precipitation technique (35). After shocking with DMSO, cells were grown in 10\% FBS for $24 \mathrm{hrs}$ and then changed to $1 \%$ FBS for $36 \mathrm{hrs}$. Cells were harvested 48-72 hrs after transfection, washed in $1 \mathrm{ml}$ of TEN ( $40 \mathrm{mM}$ Tris- $\mathrm{HCl}$, pH 7.5, $10 \mathrm{mM}$ EDTA, $150 \mathrm{mM} \mathrm{NaCl}$ ), pelleted and resuspended in $150 \mu$ of $250 \mathrm{mM}$ Tris- $\mathrm{Cl}, \mathrm{pH}$ 8.0. Lysates were generated by freeze/thawing 3 times and acetylases were inactivated by incubating at $65^{\circ} \mathrm{C}$ for $10 \mathrm{~min}$. The extract was spun for $5 \mathrm{~min}$ at $12,000 \mathrm{~g}$ and the supernatant stored at $-20^{\circ} \mathrm{C}$ until used. Protein concentrations were determined by the BCA assay (Pharmacia). Equivalent amounts of cell extract was used for each experiment. The reaction mixture consisted of $200 \mu \mathrm{g}-1 \mathrm{mg}$ of cell extract, $0.5 \mu \mathrm{Ci}{ }^{14} \mathrm{C}$-chloramphenicol, $250 \mathrm{mM}$ Tris- $\mathrm{HCl}, \mathrm{pH} 8.0$ and $3.5 \mathrm{mg} / \mathrm{ml}$ Acetyl CoA in a final volume of $180 \mu \mathrm{l}$. This mixture was incubated at $37^{\circ} \mathrm{C}$ from $2 \mathrm{hrs}$ to overnight and subsequently extracted 2 times with $250 \mu$ l ethyl acetate. The upper phases were pooled and lyophilized. The dry extract was resuspended in $15 \mu$ l ethyl acetate, applied to a TLC plate (Fischer) and chromatographed using a 95:5 (v/v) chloroform:methanol solution. Quanti- tation of radiolabeled, acetylated, chloramphenicol residues was performed using the Betascope 603 blot analyzer (Betagen, Waltham, MA).

\section{RESULTS}

TPA-mediated COL1A2, COL1A1 and COL3A1 expression in 3T3-L1 and VT-1 cells. Since we have shown
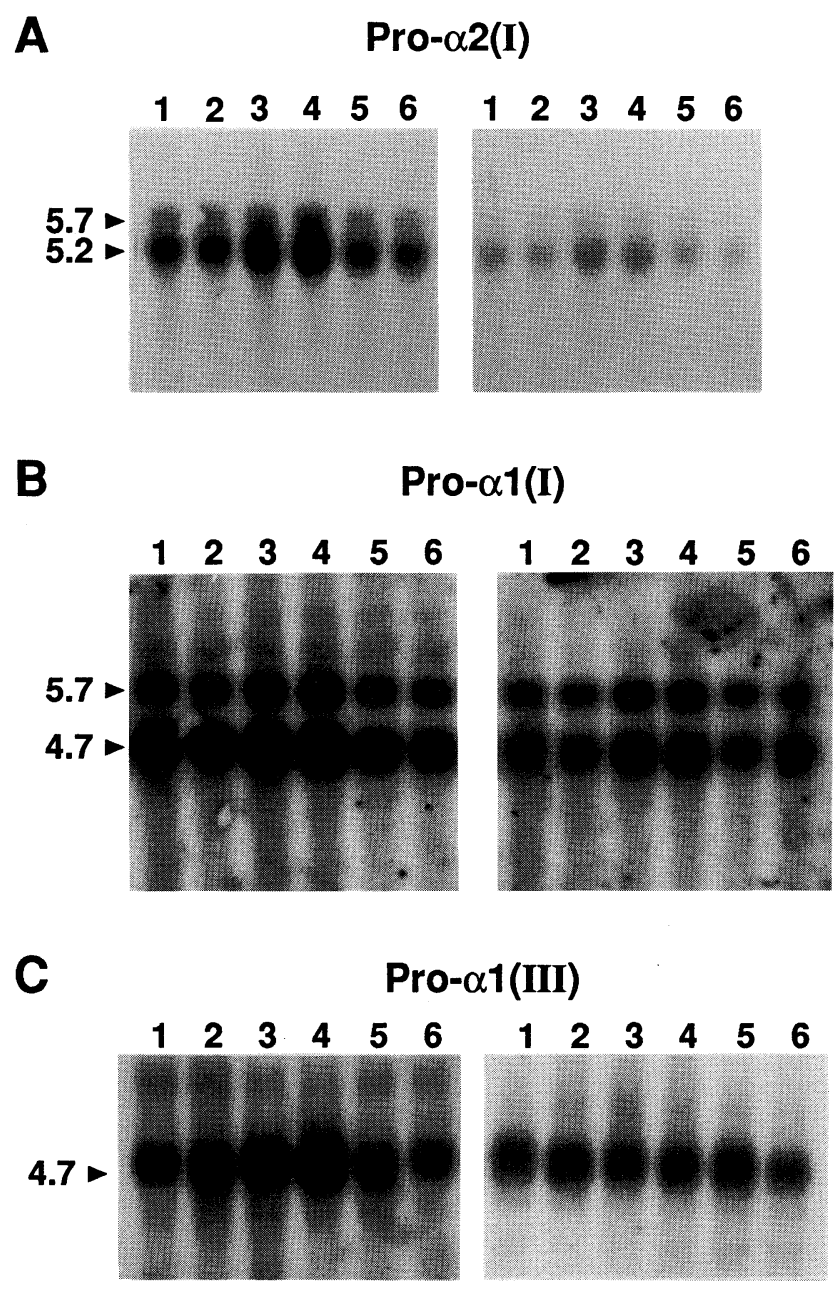

Fig. 1. TPA induced expression of Pro- $\alpha 2$ (I), Pro- $\alpha 1$ (I) and Pro$\alpha 1$ (III) mRNA in 3T3-L1 and VT-1 cells. Total RNA (5 $\mu \mathrm{gs})$ from 3T3-L1 cells (left panel) and VT-1 cells (right panel) was analyzed for specific mRNA expression by Northern blotting. Blots with 3T3-L1 RNA are shown in the left lanes 1-6 and blots with VT-1 mRNA are depicted in the right lanes 1-6. Pro- $\alpha 2$ (I) expression was monitored using the TIE-5 probe while pro- $\alpha 1$ (I) mRNA expression was analyzed using pEVE.HO (B) (E. Vuario, unpublished). Pro- $\alpha 1$ (III) mRNA expression was examined by using pMCS1.7 (C) (27). Lanes 1-5 represent $0,10 \mathrm{~min}, 20 \mathrm{~min}, 30 \mathrm{~min}, 60 \mathrm{~min}$ of TPA addition respectively. Lane 6 (A and B) contain mRNA from cells treated with DMSO $(0.1 \%)$. Lane $6 \mathrm{C}$ contains mRNA from cells treated with TPA for $2 \mathrm{hrs}$. Equal loading of total RNA was determined by EtBr staining of the gel (not shown). 
that collagen pro- $\alpha 2$ (I) mRNA is TPA inducible and differentially expressed in 3T3-L1 and VT-1 cells (26) (Fig. 1A), we explored the expression of two other fibrillar collagen mRNAs, pro- $\alpha 1$ (I) and pro- $\alpha 1$ (III) (Fig. $1 \mathrm{~B}$ and $\mathrm{C}$ ). Interestingly, TPA increased mRNA levels of both chains in 3T3-L1 cells, indicating that these genes are also expressed at the onset of a PKC mediated mitogenic signal. However, the expression levels of pro$\alpha 1$ (I) and pro- $\alpha 1$ (III) mRNA were only two-fold greater in 3T3-L1 than in VT-1 cells in contrast to pro- $\alpha 2$ (I) expression which was substantially increased in 3T3-L1 cells (Fig. 1A) (26). The induction of pro- $\alpha 1$ (I) message by TPA was more pronounced than pro- $\alpha 1$ (III) in VT1 cells.

Protooncogene $m R N A$ expression in TPA treated 3T3-LI and VT-1 cells. Protooncogenes can be viewed as genetic markers for mitogenic signal transduction pathways due to their TPA inducibility and association with cell growth regulation. We next characterized the expression of these genes in the two cell lines. Both cell lines demonstrated TPA-induciblity of protooncogenes c-fos, c-myc and c-jun mRNA (Fig. 2a-f). There were,

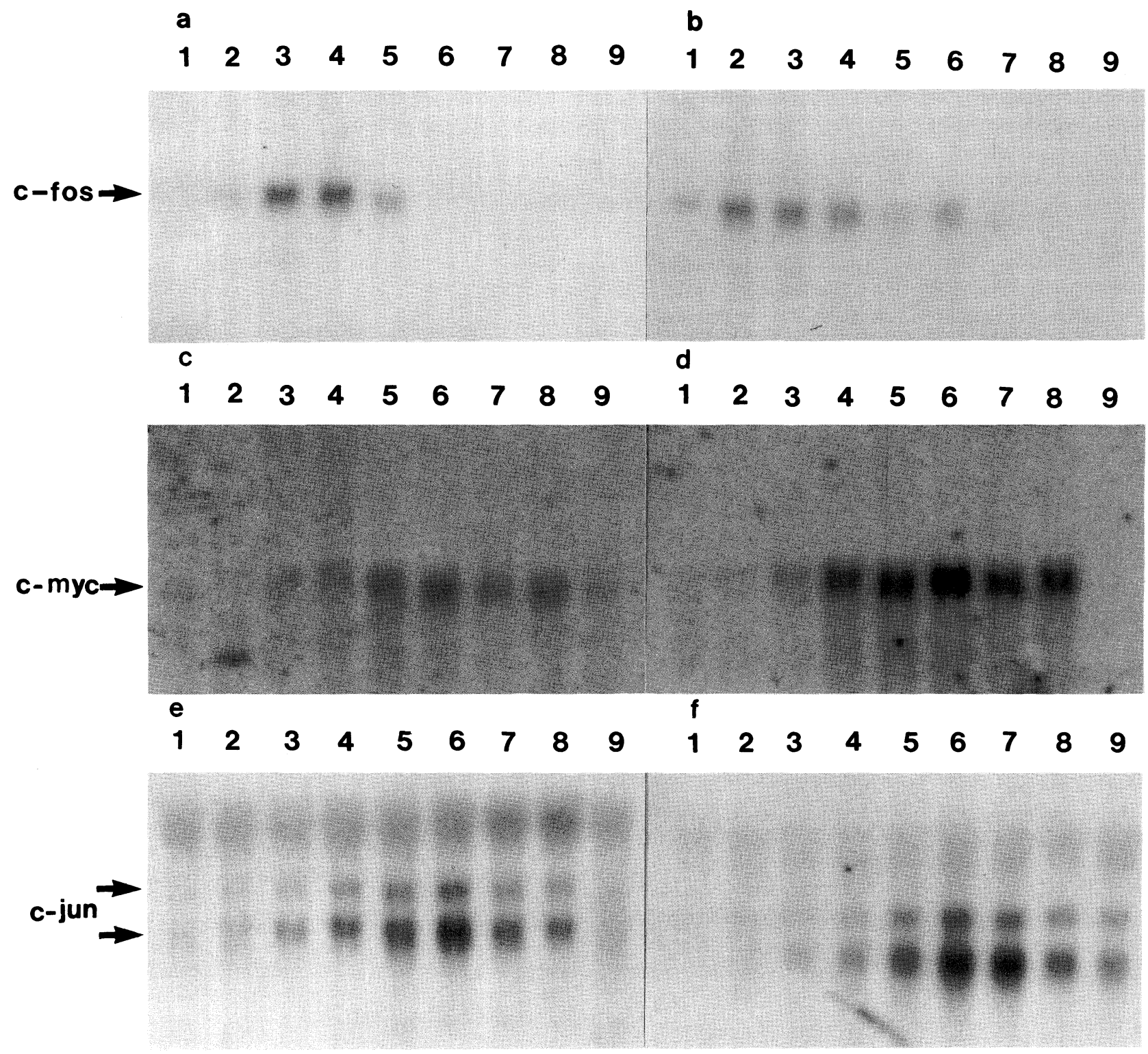

Fig. 2. TPA induction of protooncogenes c-fos, c-myc and c-jun mRNA in 3T3-L1 and VT-1 cells. Total RNA (5 $\mu$ gs) was analyzed for protooncogene mRNA expression by Northern blotting. The probes used are indicated. 3T3-L1 RNA is represented in panels a, c and e and VT-1 RNA is represented in panels b, $d$ and $\mathrm{f}$. Lanes 1-9 contain mRNA isolated from cells treated with TPA for the following times: 0, 10 min, 20 min, 30 $\mathrm{min}, 60 \mathrm{~min}, 2 \mathrm{hrs}, 6 \mathrm{hrs}, 12 \mathrm{hrs}$ and $24 \mathrm{hrs}$. Equal loading of total RNA was determined by EtBr staining of the gel (not shown). 


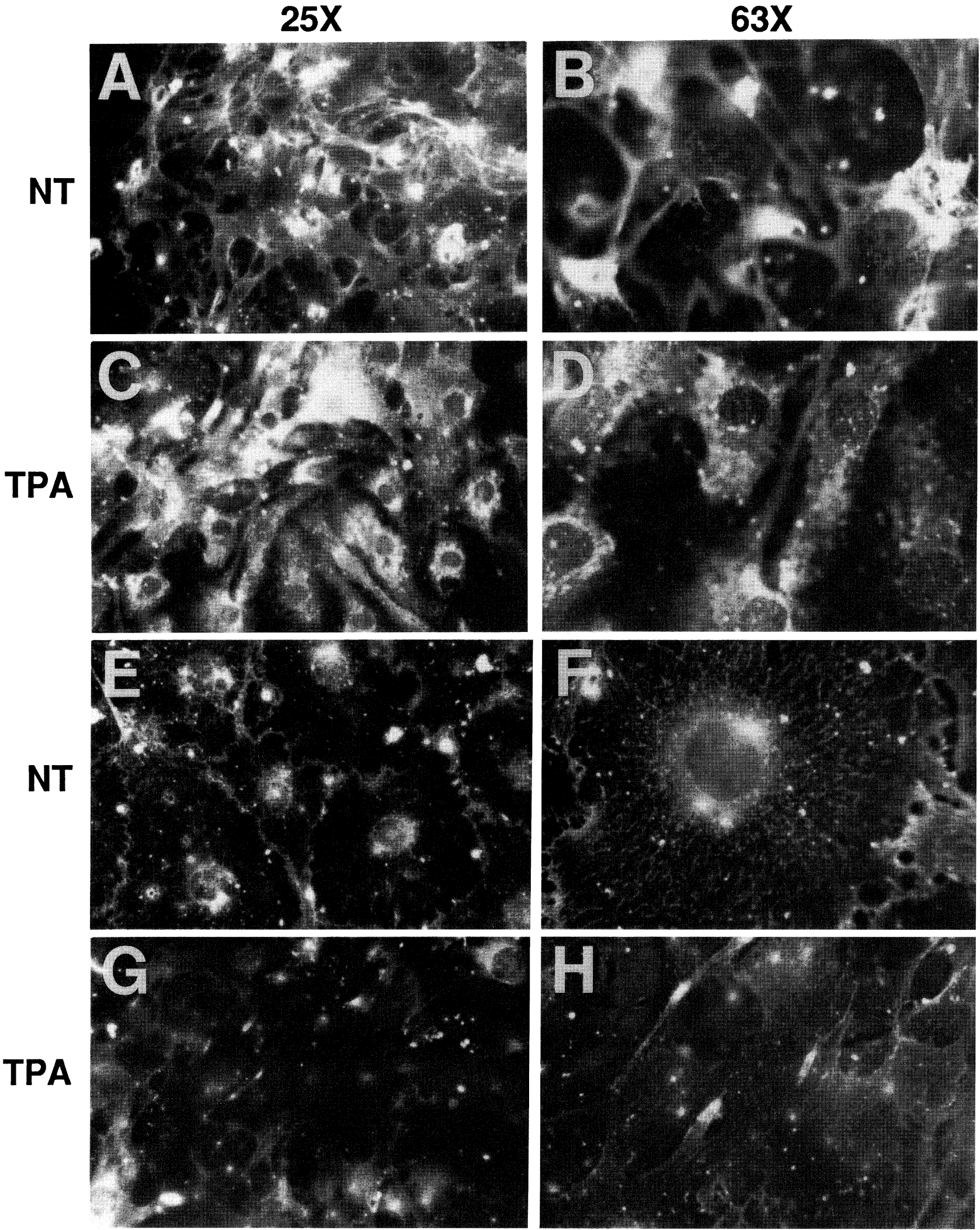

Fig. 3. 
however, differences in mRNA expression levels and turnover. Two hrs after TPA treatment, c-fos mRNA was virtually undetectable in 3T3-L1 cells but persisted for $6 \mathrm{hrs}$ in VT-1 cells (Fig. 2a, b). In addition, while a transient increase in mRNA was observable, c-myc was expressed at a level 4 to 5 times higher in VT-1 cells than in 3T3-L1 cells (Fig. 2c, d). Finally, while maximal expression of c-jun occurred at $2 \mathrm{hrs}$ in both cell lines (Fig. 2e, f), mRNA levels declined immediately in 3T3L1 cells but were maintained during a 24 hour time course in VT-1 cells. Thus regulation of protooncogene mRNA levels in these cell lines is not dependent upon activated PKC.

Increased whole cell procollagen I expression by TPA stimulated cells. Previous studies have shown that transcription and translation of procollagen type I can be regulated by TPA (26). To examine procollagen protein distribution surrounding 3T3-L1 and VT-1 cells, immunofluorescence using a rabbit anti-mouse type I procollagen antibody was performed (36). Quiescent 3T3L1 cells (Fig. 3A, B) show increased staining for procollagen type I relative to VT-1 cells (Fig. 3E, F). Assuming equal translation and secretion efficiencies, these results are consistent with the observation that basal levels of pro- $\alpha 2$ (I) mRNA were considerably lower in VT1 cells than in the parental 3T3-L1 cells (Fig. 1A). Quiescent 3T3-L1 cells stimulated with TPA show a dramatic increase in procollagen I levels (Fig. 3C, D), in contrast to VT-1 cells which maintain basal levels upon TPA treatment (Fig. 3G, $\mathrm{H}$ and Fig. 7).

TPA increases Pro- $\alpha 2$ (I) collagen mRNA by transcription. A variety of genes whose expression is modulated by mitogenic factors are regulated transcriptionally (37-39). To determine whether pro- $\alpha 2$ (I) mRNA levels are regulated at the transcriptional level, nuclear run-on transcription analysis was performed. When

Fig. 4. Nuclear run on assays reveal that TPA induced mRNA increases are regulated at the transcriptional level. 3T3-L1 cells were growth arrested and nuclei were harvested from untreated cells (A), cells treated with TPA $(100 \mathrm{ng} / \mathrm{ml})$ for $10 \mathrm{~min}(\mathrm{~B})$ and cells treated with TPA $(100 \mathrm{ng} / \mathrm{ml})$ for $10 \mathrm{~min}$ and $30 \mathrm{~min}$. (C). Nuclear transcription was performed in the presence of ${ }^{32} \mathrm{P}-\mathrm{UTP}$ for $30 \mathrm{~min}$. The labeled mRNA was extracted and used for hybridization. The following dilutions of the indicated probes were spotted onto Nytran filters: 10, $5,2.5,1.25$ and $0.612 \mu \mathrm{gs}$. pAZ1002 contains the pro- $\alpha 2$ (I) promoter $(-46$ to +54$)$, exon 1 and part of the first intron (27); TIE-5 contains the pro- $\alpha 2$ (I) carboxy terminus of COL1A2 (25) and pR23 contains the pro- $\alpha 2$ (I) promoter and $5 \mathrm{kB}$ of downstream cDNA $(+418$ to $+5,000)$. The control plasmids are pD31 ( $\beta$-actin) and pv-fos. Using the Betascope, the counts of each spot was assessed. The average cpm over three experiments was plotted (C).
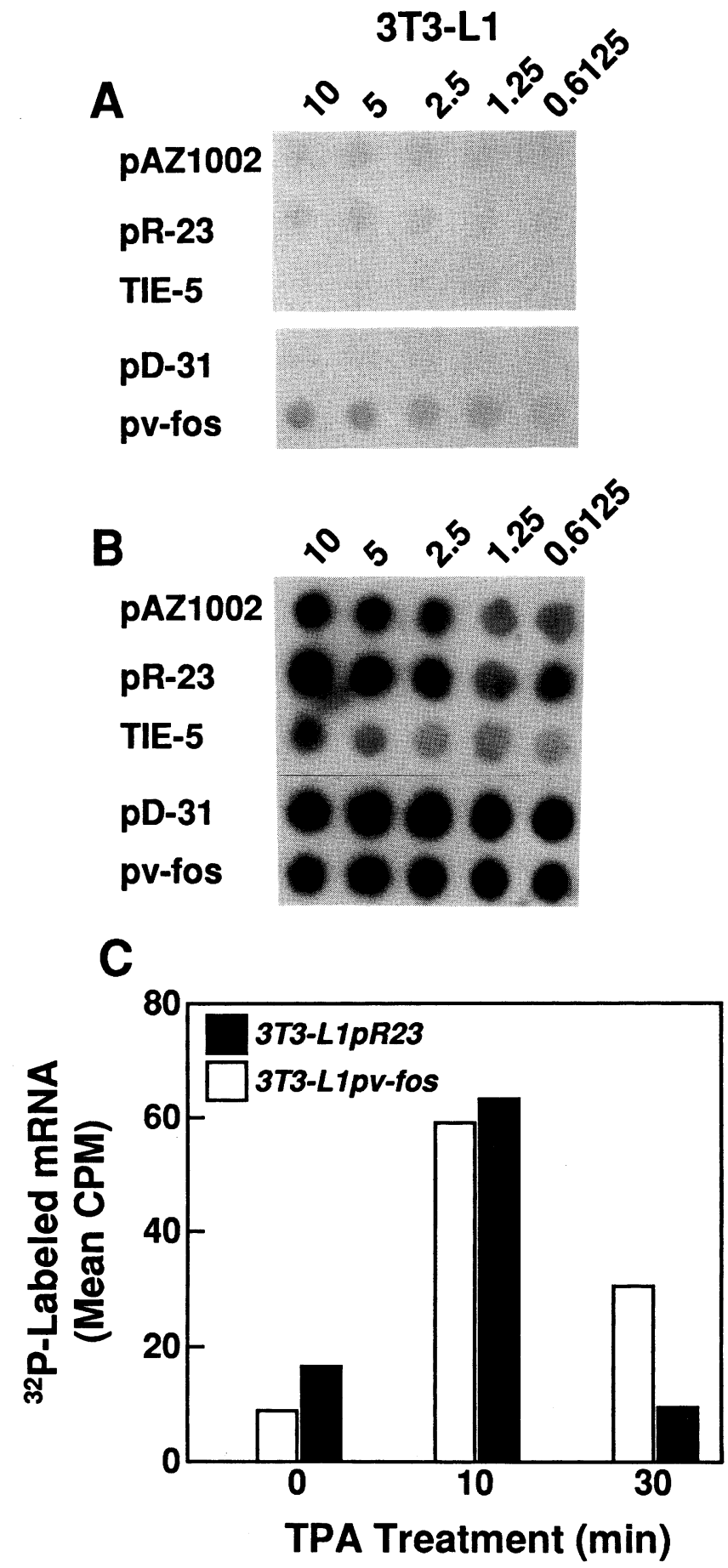

Fig. 4.

Fig. 3. Whole cell immunofluorescence of quiescent and TPA treated 3T3-L1 and VT-1 cells. 3T3-L1 (A-D) and VT-1 (E-H) cells were treated with TPA $(100 \mathrm{ng} / \mathrm{ml})(\mathrm{C}, \mathrm{D}, \mathrm{G}, \mathrm{H})$ or without (NT) (A, B, E, F) for $2 \mathrm{hrs}$. The magnification of the objective is indicated at the top. Ocular magnification was $10 \times$. Each slide depicting the indicated cells was analyzed by a BioRad laser scanning confocal microscope equipped with an MRC 600 Image Analyzer. 
cells were in a quiescent state, negligible transcription levels were observed (Fig. 4A). Within $10 \mathrm{~min}$. of TPA stimulation however, transcription levels of pro- $\alpha 2$ (I) increased greater than 4-fold (Fig. 4B, C). Expression levels of the early protooncogene c-fos (pv-fos), also increased to a maximum within 10 min of TPA stimulation (Fig. 4B and C). Peak pro- $\alpha 2$ (I) levels which appeared within $10 \mathrm{~min}$ after activation, returned to near basal levels within $30 \mathrm{~min}$. (Fig. 4C).

The Pro- $\alpha 2$ (I) promoter and first intron contain putative TPA-sensitive cis elements. The previous experiments suggest TPA initiates pro- $\alpha 2$ (I) gene transcription. TPA induced transcription is often mediated through the transcription factor AP-1 (FOS/JUN complex), which binds to the TPA responsive element (TRE) in responsive gene promoters $(4,5,40)$. The cjun gene is known to contain a TRE element within its promoter region and is therefore autoregulated by AP-1 $(4,5,41)$. The fact that c-jun mRNA expression was upregulated in both the cell lines (Fig. 2e, f) suggested that the AP-1 complex was also functional in both lines. To examine the function of AP-1 in both cell lines, we analyzed the expression of transin/stromelysin, another gene containing upstream TRE elements $(32,42)$. Like c-jun, transin mRNA was induced by TPA in both TPA responsive and non-responsive cells (Fig. 5A and $\mathrm{B}$ ). These results lend further evidence to the fact that the AP-1 complex is functional normally in both cell lines, and suggest the differential induction of pro- $\alpha 2$ (I) mRNA is not due to defects in this transcription factor.

A sequence search using the GCG Sequence Analysis Package Ver 6. (43) revealed several TRE-like sequences in the promoter and first intron of COL1A2

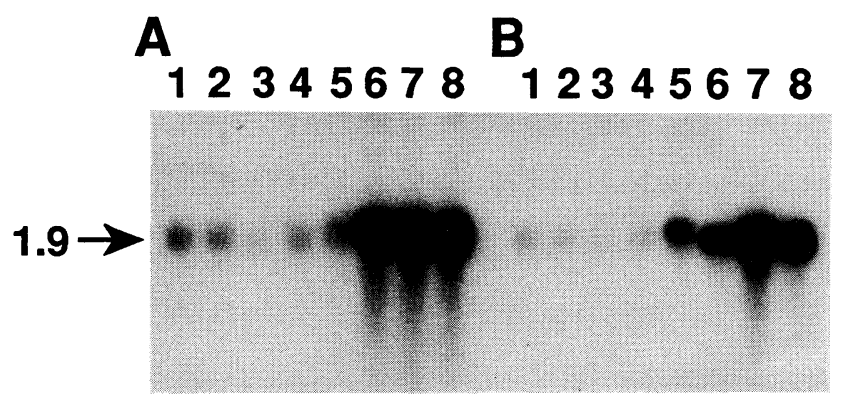

Fig. 5. TPA induced transin/stromelysin mRNA expression in 3T3L1 and VT-1 cells. Total RNA (10 $\mu \mathrm{gs})$ from 3T3-L1 (A) and VT-1 (B) was analyzed by Northern blotting. This blot was hybridized with the transin specific probe TR-1 (32). The time of TPA treatment are as follows: Lane 1: $0 \mathrm{~min}$; Lane 2: $15 \mathrm{~min}$; Lane 3: $30 \mathrm{~min}$; Lane 4: $1 \mathrm{hr}$; Lane 5: 2 hrs; Lane 6: $6 \mathrm{hrs;} \mathrm{Lane} \mathrm{7:} 12 \mathrm{hrs;} \mathrm{Lane} \mathrm{8:} 24 \mathrm{hrs}$. Equal loading of total RNA was determined by EtBr staining of the gel.

suggesting regions within the COL1A2 gene might be capable of modulating a TPA response. To assess the functional properties of these TRE-containing sequences, we used a CAT reporter construct, pR40 (35), containing $2 \mathrm{~kb}$ of the COL1A2 promoter sequence and its first intron (Fig. 6A). Transient transfection of 3T3L1 cells with pR40 demonstrated a conversion of chloramphenicol by CAT of $6 \%$ or less (Fig. 7A). CAT activity in transiently transfected 3T3-L1 cells treated with TPA (Fig. 7A, lane 3 ) was consistently $2-3$ fold greater than in either control (DMSO treated) (Fig. 7A, lane 2) or non-treated cells (Fig. 7A, lane 1). These findings indicate that the promoter and first intron of COL1A2 contain elements capable of responding to TPA.

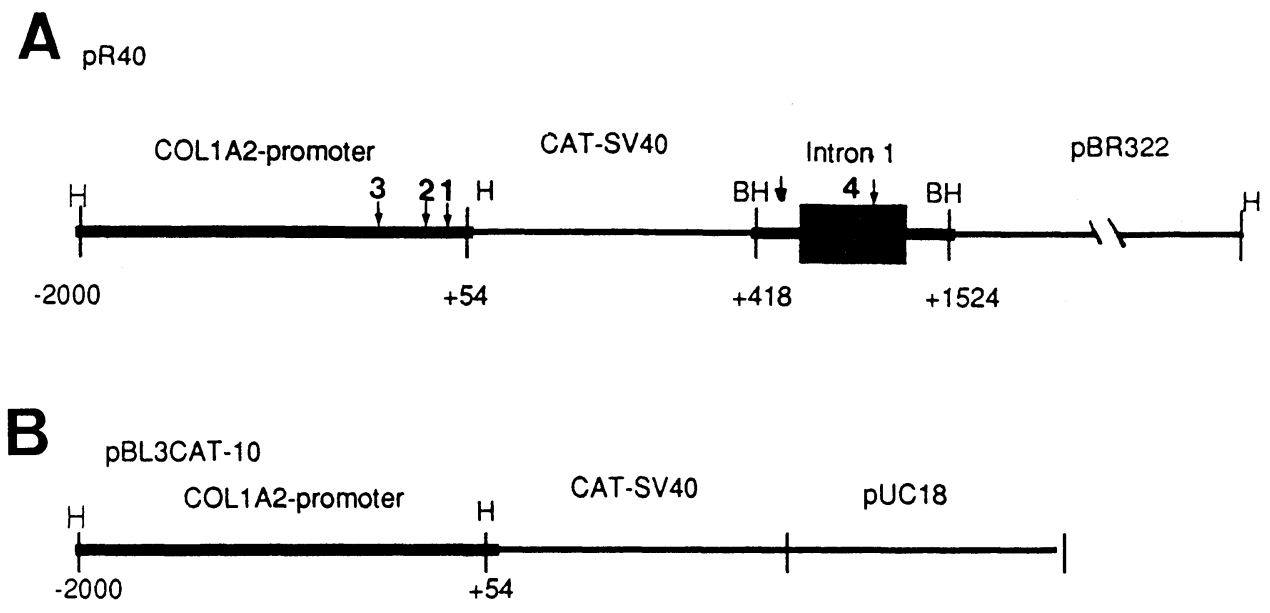

Fig. 6. Constructs of Pro- $\alpha 2$ (I) CAT reporter plasmids pR40, and pBL3CAT-10. pR40 (A) contains the COL1A2 promoter $(-2,000$ to +54$)$ and the first intron enhancer region $(+418$ to $+1,524)(28)$. PBL2CAT-10 (B) contains only the COL1A2 promoter. The numbers delineate the following: 1. TATA box, 2. CAAT box, 3. NF-1 binding site and 4. Enhancer region within the first intron (no arrow). The two arrows above the first intron indicate putative TRE elements containing a single mismatch with the consensus sequence TGACTCA. Five putative TRE sequences containing 2 mismatches were localized within the promoter region and one in the first intron (not shown). 
To assess the role of the COL1A2 promoter alone, it was cloned into the promoterless pBL3CAT (29) vector generating the construct pBL3CAT-10 (Fig. 6B). Transient transfection of this vector into 3T3-L1 cells revealed very low levels of CAT activity in cells treated with or without TPA. The low level of activity may have been due to the absence of the first intron, which contains TRE-like elements. However, transient trans-
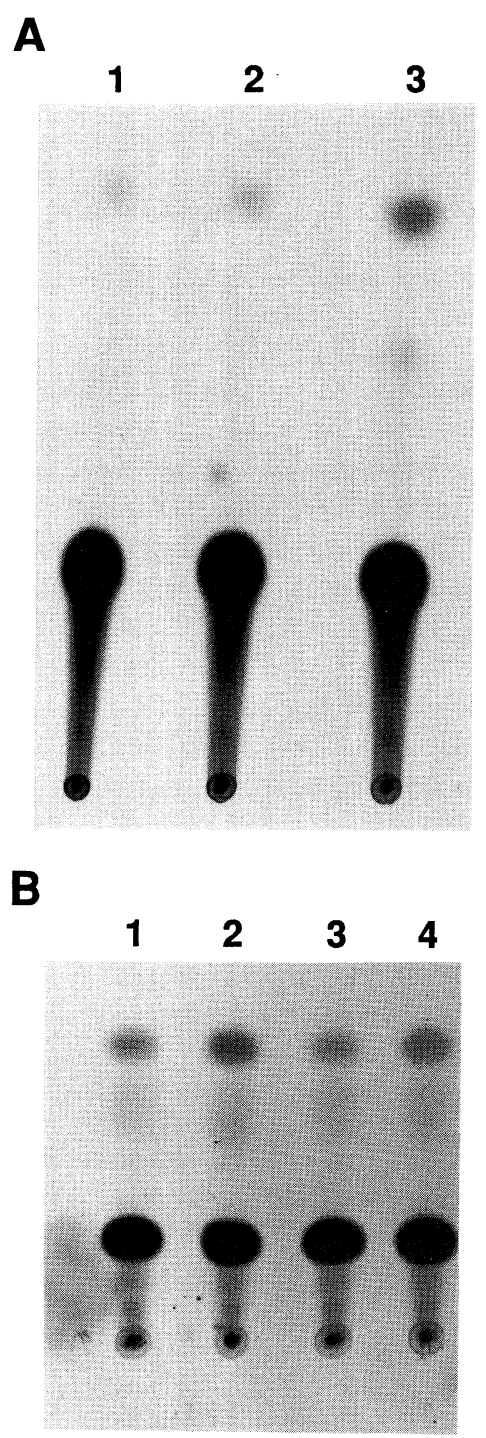

Fig. 7. Increased CAT activity in 3T3-L1 cells transfected with pR40 and pBL3CAT. (A): 3T3-L1 cells were transfected with pR40 and analyzed for CAT activity as described in the methods section. Untreated cells (lane 1); cells stimulated for $60 \mathrm{~min}$ with DMSO $(0.1 \%)$ (lane 2$)$; cells treated with TPA $(100 \mathrm{ng} / \mathrm{ml})$ for $30 \mathrm{~min}$. (lane 3). (B): CHO cells were transfected with pBL3CAT-10 and analyzed for CAT activity as described in methods section. Control cells were treated with DMSO (0.1\%) for 30 min. (lane 1 ) or 4 hrs (lane 3). Experimental cells were treated with TPA $(100 \mathrm{ng} / \mathrm{ml})$ for $30 \mathrm{~min}$. (lane 2) or 4 hrs (lane 4). fection of pBL3CAT-10 into CHO cells (Fig. 7B) demonstrated a CAT conversion of 2-4\%. TPA treatment of $30 \mathrm{~min}$ (lane 2 ) or 4 hrs (lane 4 ), demonstrated a 2fold increase in CAT conversion, confirming that the COL1A2 promoter contains a TPA responsive domain.

\section{DISCUSSION}

The expression of extracellular matrix proteins is upregulated when cells have gone from a resting to a proliferative state (44-46). In previous studies we demonstrated that pro- $\alpha 2$ (I) mRNA increased in the presence of the phorbol ester, TPA, in responsive cells (3T3-L1) but was virtually absent from cells unable to respond mitogenically to TPA (VT-1) (26). The unresponsiveness of VT-1 cells was not due to a mutant COL1A2 gene. When serum was used to induce proliferation, these cells did synthesize both pro- $\alpha 2$ (I) message and collagen protein. However, upon analysis of the subcellular distribution of PKC in TPA stimulated VT-1 cells, it became apparent that translocation of cytosolic PKC to the membrane was markedly absent as was the ability of PKC to phosphorylate its substrate, the $80 \mathrm{kD}$ protein (13). These findings have led us to suspect that TPA dependent increases in pro- $\alpha 2$ (I) mRNA are dependent upon a functional PKC population and the proliferative response of the cell.

Here we show that PKC mediated pathways differentially regulate collagen gene transcription in a cell-specific manner. Nuclear run-on experiments revealed that TPA could induce COL1A2 transcription to maximal levels within $10 \mathrm{~min}$. This rapid induction of gene transcription is typical of the immediate early gene family, a group of genes expressed at the onset of a proliferative response. Thus COL1A2 can be classified as an immediate early gene. In addition, two other closely related collagen genes COL1A1 and COL3A1 also are upregulated when quiescent cells are stimulated by TPA. Both genes have been shown to contain TRE-like elements in their regulatory domains (47-50). Interestingly, these genes exhibited similar levels of mRNA expression in both 3T3-L1 and VT-1 cells, a result consistent with the initial finding that only pro- $\alpha 2$ (I) (TIE-5) was selected by differential hybridization between the two cell lines (25).

TPA can induce the expression of immediate early genes. For example, both VT-1 and 3T3-L1 cells expressed similar message levels of c-fos, c-myc, c-jun and transin. This finding indicates that regardless of the non-functional state of PKC in the VT-1 cells, a TPA induced signal is reaching the nucleus and inducing transcription. The expression of these immediate early genes is thus independent of a functional cytosolic PKC. In addition, since VT-1 cells do not respond mitogenically to TPA, expression of these genes may be nec- 
essary but not sufficient for a mitogenic response.

While pro- $\alpha 2$ (I) collagen is not upregulated by TPA in VT-1 cells, other collagens and early response genes are. While it is not clear how TPA mediated signals are transduced in these cells, there are several possibilities. For instance, VT-1 cells might utilize a unique specific PKC isoforms to induce signaling. On the other hand, VT-1 cells still respond mitogenically to serum. Therefore, VT-1 cells might signal through growth-factor dependent pathways. Finally, the effects of TPA are pleiotropic and are capable of activating many different signaling pathways $(4,5,8,51,52)$. It is conceivable that one of these alternate routes allows for PKC independent signaling events leading to early gene expression in VT-1 cells.

There are two possible mechanisms by which PKC might mediate COL1A2 expression. First, since PKC is a serine-threonine kinase, a series of phosphorylation events might occur which ultimately transduce signals to the nucleus. The second means by which PKC may induce COL1A2 expression stems from the fact that in adherent cells, $\mathrm{PKC}$ is found at sites of contact with the extracellular matrix (focal contacts) (53). This brings PKC in close proximity to the cytoskeleton. Therefore, a translocation of PKC could induce cytoskeletal reorganization and changes in cell shape. In quiescent cells stimulated with PKC, the "cytosolic" PKC translocates to the membrane concurrent with the cell rounding up (13). This translocation event could be partially responsible for altering the cells architecture during its mitogenic response. As a consequence of the onset of the proliferative phase, the COL1A2 gene is expressed. Consistent with this idea, VT-1 cells which lack a functional $\mathrm{PKC}$, are unable to round up in the presence of TPA (unpublished observation; Stuiver and Shimizu).

Our results predict the existence of TPA responsive transcriptional elements within the COL1A2 promoter. Interestingly, COL1A 1 and COL3A1 both harbor TRE sequences in their regulatory domains (47-50). Upon sequence analysis, several TRE-like sequences were found to exist in the promoter and first intron of COL1A2. Indeed, our data indicate that the $2 \mathrm{~kb}$ region of the promoter alone can confer TPA sensitivity to the COL1A2 gene. Although the first intron does not appear to be directly responsible for TPA sensitivity, its presence did not interfere with TPA induced gene transcription.

In summary, these studies demonstrate that collagen expression is transcriptionally regulated during a proliferative response. pro- $\alpha 2$ (I) mRNA expression appears to be contingent upon a functional PKC network whereas other collagen and early gene expression can be regulated by alternative means. Identification of transcriptional regulators involved in these differential expression events might suggest novel ways to modulate gene expression and regulate cell growth.
Acknowledgements. This work was supported by a grant from the National Institutes of Health (GM24375) to NS.

\section{REFERENCES}

1. Dicker, P. and Rozengurt, E. 1981. Stimulation of DNA synthesis by transient exposure of cell cultures to TPA polypeptide mitogens: Induction of competence or incomplete removal? J. Cell. Phys., 109: 99-109.

2. Rozengurt, E. 1986. Early signals in the mitogenic response. Science, 234: 161-166.

3. Shimizu, Y., Fujiki, H., Sugimura, T., and Shimizu, N. 1986. Mouse 3T3-L1 cell variants unable to respond to mitogenic stimulation of dihydroteleocidin B: Genetic evidence for the synergism of tumor promoters with growth factors. Cancer Res., 46: 4027-4031.

4. Angel, P., Baumann, I., Stein, B., Delius, H., Rahmsdorf, H.J., and HeRRLICH, P. 1987. 12-o-tetradecanoyl-phorbol-13acetate induction of the human collagenase gene is mediated by an inducible enhancer element located in the 5 flanking region. Mol. Cell. Biol., 7: 2256-2266.

5. Angel, P., Imagawa, M., Chiu, R., Stein, B., Imbra, R.J., RahmSdorf, H.J., Jonat, C., Herrlich, P., and Karin, M. 1987. Phorbol ester-inducible genes contain a common cis element recognized by a TPA-modulated trans-acting factor. Cell, 49: 729-739.

6. HerschmanN, H.R. 1989. Extracellular signals, transcriptional responses and cellular specificity. TIBS, 14: 455-458.

7. Castagna, M., Takai, Y., Kaibuchi, K., Sano, K., KikKawa, U., and NishizuKa, Y. 1982. Direct activation of calcium-activated, phospholipid-dependent protein kinase by tumor-promoting esters. J. Biol. Chem., 257: 7847-7851.

8. NishizUKA, Y. 1986. Studies and perspectives of protein kinase C. Science, 233: 305-312.

9. NishizUKa, Y. 1989. The Albert Lasker Medical Awards. The family of protein kinase $\mathrm{C}$ for signal transduction. JAMA, 262: 1826-1833.

10. NishizUKA, Y. 1992. Intracellular signaling by hydrolysis of phospholipids and activation by protein kinase C. Science, 258: 607-614.

11. Bell, R.M. 1986. Protein kinase $\mathrm{C}$ activation by diacylglycerol second messengers. Cell, 45: 631-632.

12. Kuo, J.F., Andersson, R.G.G., Wise, B.C., Mackerlova, L., Salmonsson, I., Brackett, N.L., Katoh, N., Shois, M., and WrenN, R.W. 1980. Calcium-dependent protein kinase: Widespread occurrence in various tissues and phyla of the animal kingdom and comparison of effects of phospholipid, calmodulin and trifluoperazine. Proc. Natl. Acad. Sci. USA, 77: 7039-7043.

13. Shimizu, Y. and Shimizu, N. 1989. Cell genetic evidence of correlation of intracellular translocation of protein kinase C (PKC) and $\mathrm{PKC}$-mediated phosphorylation of $80-\mathrm{kDa}$ protein with mitogenic action of tumor promoters. Somat. Cell Mol. Genet., 15: 321-329.

14. Werth, D.K., Niedel, J.E., and Pastan, I. 1983. Vinculin, a cytoskeletal substrate of protein kinase C. J. Biol. Chem., 258: 11423-11426.

15. Witters, L.A., Vacter, C.A., and Lienhard, G.E. 1985. Phosphorylation of the glucose transporter in vitro and in vivo by protein kinase C. Nature, 315: 777-778.

16. BERRIDGE, M.J. 1986. Growth factors, oncogenes and inositol lipids. Cancer Surveys, 5: 413-430. 
17. Bohmann, D. and Tijan, R. 1989. Biochemical analysis of transcriptional activation by Jun: Differential activity of c- and v-Jun. Cell, 59: 709-717.

18. Cohen, D.R., Ferreira, P.C.P., Gentz, R., Franza, B.R. JR., and CuRran, T. 1989. The product of a fos-related gene, fra-1, binds cooperatively to the AP-1 site with Jun: Transcription factor AP-1 is comprised of multiple protein complexes. Genes Dev., 3: 173-184.

19. Johnson, M.D., Housey, G.M., O'Brian, C.A., Kirschmeier, P.T., and Weinstein, I.B. 1987. Role of protein kinase C in regulation of gene expression and relevance to tumor promotion. Environmental Health Perspectives, 76: 89-95.

20. Rauscher, F.J. III, Cohen, D.R., Curran, T., Bos, T.J., Vogt, P.K., Bohmann, D., Tijan, R., and Franza, B.R. JR. 1988. Fos-associated protein $\mathrm{p} 39$ is the product of the jun proto-oncogene. Science, 240: 1010-1016.

21. Ryder, K., LaU, L.F., and Nathans, D. 1988. A gene activated by growth factors is related to the oncogene v-jun. Proc. Natl. Acad. Sci. USA, 85: 1487-1491.

22. Ryder, K., Lanahan, A., Perez-Albuerne, E., and Nathans, D. 1989. jun-D: A third member of the jun gene family. Proc. Natl. Acad. Sci. USA, 86: 1500-1503.

23. Yoshimasa, T., Sibley, D.R., Bouvier, M., LefKowitz, R.J., and CARON, M.G. 1987. Cross-talk between cellular signalling pathways suggested by phorbol-ester-induced adenylated cyclase phosphorylation. Nature, 327: 67-70.

24. Zerial, M., Toschi, L., Rysseck, R.P., Schuermann, M., Muller, R., and Bravo, R. 1989. The product of a novel growth factor activated gene, fos B, interacts with JUN proteins enhancing their DNA binding activity. EMBO J., 8: 105-113.

25. Amagai, M., Inokuchi, Y., Nishikawa, T., Shimizu, Y., and Shimizu, N. 1989. Cloning of TPA-inducible early (TIE) genes by differential hybridization using a TPA-nonresponsive variant of mouse 3T3-L1 cells. Somat. Cell Mol. Genet., 15: 153-158.

26. Stuiver, I., Shimizu, Y., and Shimizu, N. 1991. Phorbol-ester-mediated expression of the collagen type I pro-alpha 2 gene in mouse 3T3-L1 cells and its absence in a phorbol 12-myristate13-acetate-non-responsive variant. Biochem. J., 278: 369-373.

27. Liau, G., Yamada, Y., and de Crombrugghe, B. 1985. Coordinate regulation of the levels of type III and type I collagen mRNA in most but not all mouse fibroblasts. J. Biol. Chem., 260: 531-536.

28. Rossi, P. and de CrombrugGhe, B. 1987. Identification of a cell-specific transcriptional enhancer in the first intron of the mouse alpha 2 (type I) collagen gene. Proc. Natl. Acad. Sci. (USA), 84: 5590-5594.

29. Luckow, B. and SchuTz, G. 1987. CAT constructions with multiple unique restriction sites for the functional analysis of eukaryotic promoters and regulatory elements. Nucleic Acids Res., 115: 5490-5496.

30. Van Beveren, C., Van Straaten, F., Curran, T., Muller, R., and Verma, I.M. 1983. Analysis of FBJ-MuSV provirus and c-fos (mouse) gene reveals that viral and cellular fos gene products have different carboxy termini. Cell, 32: 1241-1255.

31. Bohmann, D., Bos, T.J., Admon, A., Nishimura, T., Vogt, P.K., and TIJAN, R. 1987. Human proto-oncogene c-jun encodes a DNA binding protein with structural and functional properties of transcription factor AP-1. Science, 238: 13861392.

32. Matrisian, L.M., Leroy, P., Ruhlmann, C., Gesnel, M.C., and BreAtHNACH, R. 1986. Isolation of the oncogene and epidermal growth factor-induced transin gene: Complex control in rat fibroblasts. Mol. Cell. Biol., 6: 1679-1686.

33. Shimizu, Y. and Shimizu, N. 1980. Genetics of cell-surface receptors for bioactive polypeptides: A variant of mouse Balbc /3T3 fibroblasts possessing altered insulin-binding ability. Somat. Cell Genet., 6: 583-601.

34. Chirgwin, J.M., Przybyla, A.E., McDonald, R.J., and RUTTER, W.J. 1979. Isolation of biologically active ribonucleic acid from sources enriched in ribonuclease. Biochemistry, 18: 5294-5299.

35. Sassone-Corsi, P., Ransone, L.J., Lamph, W.W., and Verma, I.M. 1988. Direct interaction between fos and jun nuclear oncoproteins: Role of the leucine zipper domain. Nature, 336: 692-695.

36. Shiba, Y., Sastrodihardjo, S., SASaki, Y., and Kanno, Y. 1987. Intracellular contacts and the organization of actin filaments in cultured epithelial FL cells are altered by growth on type I collagen and treatment with 12-o-tetradecanoylphorbol13-acetate through the modulation of interactions between cells and the substratum. Cell Struct. Funct., 12: 549-558.

37. Almendral, J.M., Sommer, D., Macdonald-Bravo, H., BurCKhardt, J., Perera, J., and Bravo, R. 1988. Complexity of the early genetic response to growth factors in mouse fibroblasts. Mol Cell Biol., 8: 2140-2148.

38. Curran, T. and Franza, B.R. JR. 1988. Fos and Jun: The AP-1 connection. Cell, 55: 395-397.

39. Nathans, D., Lau, L.F., Christy, B., Hartzell, S., NAKABEPPU, Y., and RYDeR, K. 1988. Cold Spring Harbor Symposia on Quantitative Biology, Vol.LIII. Cold Spring Harbor Laboratory, pp.893-900.

40. Pennypacker, K.R., Hong, J.S., and McMillian, M.K. 1994. Pharmacological regulation of AP-1 transcription factor DNA binding activity. FASEB J., 8: 475-478.

41. Norman, C., Runswick, M., Pollock, R., and Treisman, R. 1988. Isolation and properties of cDNA clones encoding SRF, a transcription factor that binds to the c-fos serum response element. Cell, 55: 989-1003.

42. Lee, W., Haslinger, A., Karin, M., and Tuian, R. 1987. Activation of transcription by two factors that bind promoter and enhancer sequences of the human metallothionein gene and SV40. Nature, 325: 368-372.

43. Devereux, J., Haeberli, P., and Smithies, O. 1984. A comprehensive set of sequence analysis programs for the VAX. Nuc. Acids Res., 12: 387-395.

44. Blatti, S.P., Foster, D.N., Ranganathan, G., Moses, H.L., and GetZ, M.J. 1988. Induction of fibronectin gene transcription and mRNA is a primary response to growth-factor stimulation of AKR-2B cells. Proc. Natl. Acad. Sci. USA, 85: 11191123.

45. Ben-Ze'ev, A., Robinson, G.S., Bucher, N.L.R., and FARMER, S.R. 1988. Cell-cell and cell-matrix interactions differentially regulate the expression of hepatic and cytoskeletal genes in primary cultures of rat hepatocytes. Proc. Natl. Acad. Sci. USA, 85: 2161-2165.

46. Ben-Ze'ev, A., Reiss, R., Bendori, R., and Gorodecki, B. 1990. Transient induction of vinculin gene expression in 3 T3 fibroblasts stimulated by serum-growth factors. Cell Reg., 1: 621-636.

47. Benson-Chanda, V., Su, M.W., Weil, D., Chu, M.L., and RAMIREZ, F. 1989. Cloning and analysis of the 5' portion of the human type-III procollagen gene (COL3A1). Gene, 78: 255-65.

48. Katai, H., Stephenson, J.D., Simkevich, C.P., Thompson, J.P., and RAGHOW, R. 1992. An AP-1-like motif in the first intron of human Pro alpha 1 (I) collagen gene is a critical deter- 
minant of its transcriptional activity. Mol. Cell. Biochem., 118: 119-129.

49. Liska, D.J., Robinson, V.R., and Bornstein, P. 1992. Elements in the first intron of the alpha 1 (I) collagen gene interact with Sp1 to regulate gene expression. Cell Regul., 1: 487-498.

50. Mä̈̈tт̈̈, A., Glumoff, V., PaAkkonen, P., Liska, D.J., PenTTINEN, R.P.K., and ElimA, K. 1993. Nuclear factor binding to AP-1 site is associated with the activation of pro- $\alpha 1$ (I)-collagen gene in dedifferentiating chondrocytes. Biochem. J., 294: $365-371$.
51. Angel, P., Poting, A., Mallick, U., Rahmsdorf, H.J., SCHORPP, M., and HerRLICH, P. 1986. Induction of metallothionein and other mRNA species by carcinogens and tumor promoters in primary human skin fibroblasts. Mol. Cell. Biol., 6: $1760-1766$.

52. Chiu, R., Imagawa, M., Imbra, R.J., Bockoven, J.R., and KARIN, M. 1987. Multiple cis- and trans-acting elements mediate the transcriptional response to phorbol esters. Nature, 329: 648-651.

53. Woods, A. and Couchman, ?. 1992. Protein kinase C involvement in focal adhesion formation. J. Cell Science, 101: 277290.

(Received for publication, July 4, 1996) 